\title{
Pengaruh Model Market Place Activity (MPA) Berbantuan Poster Terhadap Prestasi Belajar Siswa Kelas V SD IT At- Taufiq Al-Islamy Pada Tema 6 Subtema 1 Muatan IPA
}

\author{
Ifa Nur Afifah ${ }^{1}$, Moh.Fahmi Nugraha ${ }^{2}$, Budi Hendrawan ${ }^{3}$ \\ ${ }^{1}$ Universitas Muhammadiyah Tasikmalaya; ifanurafifah10@gmail.com \\ ${ }^{2}$ Universitas Muhammadiyah Tasikmalaya; m.fahminugraha@umtas.ac.id \\ 3Universitas Muhammadiyah Tasikmalaya; hendrawan budy@umtas.ac.id
}

\begin{abstract}
Abstrak. Penelitian ini bertujuan untuk mengetahui pengaruh Model Market Place Activity (MPA) Berbantuan Poster Terhadap Prestasi Belajar Siswa Kelas V SD IT AtTaufiq Al-Islamy Pada Tema 6 Subtema 1 Muatan IPA. Penelitian ini termasuk penelitian eksperimen semu (quasi eksperimen) menggunakan desain Pretest-Posttest Nonequivalent control group design. Populasi dalam penelitian ini adalah seluruh siswa kelas V SD IT At-Taufiq Al-Islamy, yang berjumlah 20 siswa dan pengambilan sampel dengan menggunakan teknik Sampling Jenuh. Sampel diambil secara random yang menghasilkan 10 siswa kelas eksperimen dan 10 siswa kelas kontrol. Berdasarkan hasil penelitian diperoleh bahwa dengan menggunakan model Market Place Activity (MPA) berbantuan poster dapat memengaruhi prestasi belajar siswa Kelas V SD IT At-Taufiq Al-Islamy Pada Tema 6 Subtema 1 Muatan IPA, hal ini juga terlihat dari perbedaan antara rata-rata prestasi belajar pada kelas eksperimen dan kelas kontrol, pada kelas eksperimen rata-ratanya yaitu 84,8 dan rata-rata prestasi belajar pada kelas kontrol yaitu 66,2.
\end{abstract}

Kata kunci: Market Place Activity (MPA) Berbantuan Poster, Prestasi Belajar IPA

Abstract. This study aims to determine the effect of Poster Assisted Market Place Activity (MPA) Models on Learning Achievement of Class V Students of SD IT At-Taufiq Al-Islamy On Theme 6 Subtema 1 The Science Content. This study was a quasi-experimental study (quasiexperimental) using the Pretest-Posttest Nonequivalent control group design. The population in this study were all fifth grade students of At-Taufiq Al-Islamy Elementary School, totaling 20 students and sampling using the Saturated Sampling technique, The samples are taken randomly, which resulted 10 experimental class students and 10 control class students. Based on the results of the study, it was found that there is an influence of the Market Place Activity

Caruban: Jurnal Ilmiah Pendidikan Dasar 3(1), 93-106, Januari 2020

DOI: http://dx.doi.org/10.33603/.v3i1.3278, p-ISSN 2615-1391, e-ISSN 2620-3219

CProdi PGSD Universitas Swadaya Gunung Jati 
Model (MPA) Assisted Poster Against Student Achievement Class V SD IT At-Taufiq AlIslamy Elementary School On Theme 6 Subtheme 1 Science Content, this can also be seen from the difference between the average learning achievement in the experimental class $(84,8)$ and the average learning achievement in the control class (66.2).

Keywords: Poster Assisted Market Place Activity (MPA), Natural Science Learning Achievement

\section{Pendahuluan}

Pendidikan adalah suatu proses pembelajaran kepada peserta didik agar memiliki pemahaman terhadap sesuatu dan membuatnya menjadi seorang manusia yang kritis dalam berpikir. Mengingat fungsi dan tujuan pendidikan Nasional yang tercantum dalam Undang-undang nomor 20 tahun 2003, Pasal 3 yang menyebutkan bahwa pendidikan nasional itu sebagaimana fungsinya untuk mengembangkan kemampuan dan membentuk watak serta peradaban bangsa yang bermartabat dalam rangka mencerdaskan kehidupan bangsa. Untuk mencapai fungsi dan tujuan tersebut, guru harus melibatkan siswa dalam proses pembelajaran, sehingga siswa dapat berperan aktif dalam belajar dan dapat mengembangkan kemampuannya. Banyak cara yang dapat dilakukan oleh guru untuk membuat peserta didik aktif, antara lain penerapan model-model pembelajaran. Model pembelajaran diartikan sebagai prosedur dalam melaksanakan pembelajaran untuk mencapai tujuan belajar atau dapat diartikan sebagai suatu pendekatan yang digunakan dalam kegiatan pembelajaran untuk mencapai tujuan yang telah dirumuskan. Saat ini telah banyak dikembangkan berbagai macam model pembelajaran, dimana dari setiap model pembelajaran mempunyai kelebihan dan kekurangan sendiri.

Salah satu model pembelajaran yang melibatkan peranan siswa dalam belajar yaitu model pembelajaran Market Place Activity (MPA) berbantuan poster. Model Pembelajaran Market Place Activity (MPA) merupakan model pembelajaran berupa kegiatan pasar, dimana siswa dapat melakukan jual beli informasi. Terdapat kelompok siswa pemilik informasi untuk dijual kepada kelompok lain dan kelompok siswa yang membeli informasi. Informasi yang dijualbelikan adalah materi yang dipelajari pada hari itu. Bantuan media

Caruban: Jurnal Ilmiah Pendidikan Dasar 3(1), 93-106, Januari 2020

DOI: http://dx.doi.org/10.33603/.v3i1.3278, p-ISSN 2615-1391, e-ISSN 2620-3219

CProdi PGSD Universitas Swadaya Gunung Jati 
poster membuat siswa lebih mudah dalam menyampaikan informasi ke kelompok lain dan kelompok lain akan lebih mudah memahaminya. Menurut Sanaky dalam Niska (2013: 2), " poster adalah gambar dengan ukuran besar dan memberi tekanan pada satu atau dua ide pokok yang divisualisasikan secara sederhana dan jelas."

Penggunaan model pembelajaran Market Place Activity (MPA) berbantuan poster ini diharapkan bisa meningkatkan prestasi belajar. Prestasi belajar merupakan hasil yang dicapai oleh seseorang setelah ia melakukan kegiatan belajar. Djamarah (2017: 23) menyatakan bahwa "prestasi belajar adalah hasil yang diperoleh berupa kesan-kesan yang mengakibatkan perubahan dalam diri individu sebagai hasil dari aktivitas dalam belajar." Salah satu pelajaran di sekolah dasar yaitu Ilmu Pengetahuan Alam (IPA). Ilmu Pengetahuan Alam merupakan mata pelajaran yang memelajari peristiwa-peristiwa yang terjadi di alam. IPA merupakan salah satu mata pelajaran di sekolah dasar yang dinilai memegang peranan penting, kareana IPA merupakan pengetahuan tentang alam yang sering dijumpai dalam kehidupan sehari-hari siswa. Salah satu materi IPA yang dipelajari di kelas V adalah Suhu dan Kalor yang ada di tema 6 subtema 1 pembelajaran 1, 2 dan 5 .

Berdasarkan wawancara kepada Ibu Risma, selaku guru kelas V di SD IT AtTaufiq Al-Islamy, bahwa hasil ulangan pada tema 6 subtema 1 muatan IPA pada tahun ajaran 2018/2019 masih rendah, hal ini terlihat dari data hasil ulangan bahwa dari 18 siswa terdapat 7 siswa (45\%) yang sudah tuntas dan 12 siswa (55\%) yang belum tuntas dan kegiatan belajar yang masih menggunakan model ceramah, dimana siswa hanya duduk diam dan mendengarkan materi. Sedangkan menurut Sumantri (2015: 154), karakteristik siswa SD yaitu senang bermain, senang bergerak, anak senang bekerja dalam kelompok, dan senang merasakan atau melakukan/memeragakan secara langsung. Kegiatan pembelajaran yang tidak melibatkan anak berperan aktif dalam proses pembelajaran membuat anak jenuh, peserta didik menjadi pasif dan kurang aktif, sehingga banyak peserta didik yang ribut dan bercanda dengan temannya,

Caruban: Jurnal Ilmiah Pendidikan Dasar 3(1), 93-106, Januari 2020

DOI: http://dx.doi.org/10.33603/.v3i1.3278, p-ISSN 2615-1391, e-ISSN 2620-3219

CProdi PGSD Universitas Swadaya Gunung Jati 
hal tersebut jelas akan berdampak pada rendahnya prestasi belajar peserta didik.

Berdasarkan kondisi tersebut perlu adanya penggunaan model pembelajaran yang dapat melibatkan siswa aktif dan membantu peserta didik dalam meningkatkan prestasi belajar kelas $\mathrm{V}$ di tahun ajaran berikutnya, pada tahun ajaran 2019/2020 tema 6 subtema 1 muatan IPA. Agar siswa dapat belajar secara aktif dan meningkatkan prestasi belajar pada tema 6 subtema 1 muatan IPA, maka perlu dilakukan penelitian tentang pengaruh model Market Place Activity (MPA) berbantuan poster terhadap prestasi belajar kelas V SD IT At-Taufiq AlIslamy pada tema 6 subtema 1 muatan IPA.

\section{Metode Penelitian}

Dalam penelitian ini metode yang digunakan adalah metode penelitian eksperimen. Menurut Sugiyono (2016: 107), “metode eksperimen dapat diartikan sebagai metode penelitian yang digunakan untuk mencari pengaruh perlakuan tertentu terhadap yang lain dalam kondisi yang terkendalikan." Alasan kenapa peneliti memilih penelitian eksperimen karena suatu eksperimen dimaksudkan untuk menilai pengaruh suatu model pembelajaran Market Place Activity (MPA) berbantuan poster terhadap prestasi belajar pada tema 6 subtema 1 muatan IPA. Perbedaan perlakuan antara kelompok eksperimen dan kelompok kontrol ialah bahwa pada kelompok eksperimen diberi perlakuan model pembelajaran Market Place Activity (MPA) berbantuan poster, sedangkan pada kelompok kontrol menggunakan metode ceramah. Penelitian ini menggunakan jenis penelitian quasi eksperimental. Sukmadinata (2016: 207) menyatakan bahwa Quasi Eksperimental ini disebut kuasi karena bukan merupakan eksperimen murni tapi seperti murni, seolah-olah murni. Eksperimen ini juga disebut eksperimen semu. Karena berbagai hal, terutama berkenaan dengan pengontrolan variabel, kemungkinan sukar sekali dapat digunakan eksperimen murni. Eksperimen kuasi bisa digunakan minimal kalau dapat mengontrol satu variabel saja meskipun dalam bentuk matching, atau memasangkan atau menjodohkan karakteristik kalau bisa random lebih baik.

Caruban: Jurnal Ilmiah Pendidikan Dasar 3(1), 93-106, Januari 2020

DOI: http://dx.doi.org/10.33603/.v3i1.3278, p-ISSN 2615-1391, e-ISSN 2620-3219

CProdi PGSD Universitas Swadaya Gunung Jati 
Populasi dalam penelitian ini yaitu seluruh siswa kelas V SD IT At-Taufiq AlIslamy yang berjumlah 20 siswa. Menurut Indrawan dan Yaniawati (2017: 93), "Populasi adalah kumpulan dari keseluruhan elemen yang akan ditarik kesimpulanya." Sampel yang digunakan dalam penelitian ini yaitu sampel jenuh, Sugiyono (2016: 124) menyatakan bahwa Sampling jenuh adalah teknik penentuan sampel bila semua anggota populasi digunakan sebagai sampel. Hal ini sering dilakukan bila jumlah populasi relatif kecil, kurang dari 30 orang, atau penelitian yang ingin membuat generalisasi dengan kesalahan yang sangat kecil. Istilah lain sampel jenuh adalah sensus dimana semua anggota populasi dijadikan sampel. Dalam penelitian ini populasinya berjumlah 20 siswa jadi peneliti mengambil teknik sampel jenuh sehingga semua siswa dijadikan sebagai sampel. Sampel dari penelitian ini adalah kelas V SD IT At-Taufiq AlIslamy, sebagai kelompok kontrol 10 siswa dan sebagai kelompok eksperimen 10 siswa, pembagian kelompok ini dilakukan dengan teknik random, yaitu seluruh siswa dibagi acak menggunakan kocokan arisan, siswa menggambil kertas kocokan satu persatu. Siswa yang mendapat nomor bilang ganjil akan masuk kelompok eksperimen, sedangkan siswa yang dapat nomor bilangan genap akan masuk kelompok kontrol.

Teknik pengumpulan data yang digunakan dalam penelitian ini adalah teknik tes dan dokumentasi. Tes yang digunakan dalam penelitian ini berupa pretest (sebelum diberikan perlakuan dan posttest (setelah diberikan perlakuan). Soal diujicobakan dengan melakukan uji validitas, reliabilitas, dan daya pembeda. Hal tersebut dilakukan untuk mengetahui adanya pengaruh model pembelajaran Market Place Activity (MPA) Berbantuan Poster terhadap prestasi belajar siswa kela V SD IT At-Taufiq Al-Islamy Pada Tema 6 Subtema 1 Muatan IPA. Sedangkan teknik dokumentasi pada penelitian ini yaitu berbagai data sekunder berupa hal-hal yang berkaitan dengan prestasi belajar siswa di SD IT At-Taufiq Al-Islamy, diantaranya profil sekolah, nilai pretest, posttest, dan fotofoto saat proses pembelajaran di kelas ekspermen dan di kelas kontrol.

Setelah seluruh data terkumpul, maka dilakukan teknik analisis data dengan tujuan mengelolah data tersebut untuk menjawab rumusan masalah. Teknik

Caruban: Jurnal Ilmiah Pendidikan Dasar 3(1), 93-106, Januari 2020

DOI: http://dx.doi.org/10.33603/.v3i1.3278, p-ISSN 2615-1391, e-ISSN 2620-3219

CProdi PGSD Universitas Swadaya Gunung Jati 
analisis data dalam penelitian ini meliputi uji prasyarat analisis, analisis data pretest dan analisis data posttest yang diuji menggunakan aplikasi SPSS versi 23 dengan taraf signifikansi 0,05, yaitu uji normalitas, uji homogenitas, uji t dua sampel independen serta uji paired sampel t test.

\section{Hasil dan Pembahasan}

Penelitian ini dilaksanakan pada semester ganjil tahun ajaran 2019/2020 di SD IT At-Taufiq Al-Islamy Jl. Batara, Kelurahan Kahuripan, Kecamatan Tawang, Kota Tasikmalaya, Jawa Barat. Penelitian ini dimulai pada tanggal 02 Oktober 2019 sampai dengan 15 Januari 2020. Sampel yang digunakan adalah sampling jenuh karena seluruh populasi dalam penelitian ini dijadikan sebagai sampel penelitian. Sampel dari penelitian ini adalah kelas V SD IT At-Taufiq Al-Islamy, sebagai kelompok kontrol 10 siswa dan sebagai kelompok eksperimen 10 siswa. Pada kelas eksperimen dilakukan pembelajaran menggunakan model Market Place Activity (MPA) Berbantuan Poster, sedangkan pada kelas kontrol dilakukan pembelajaran menggunakan model konvesional (ceramah). Pada data nilai pretest dan posttest kemudian dilakukan uji prasyarat analisis, yaitu uji normalitas dan uji homogenitas dan uji hipotesis dengan menggunakan bantuan SPSS versi 23 dengan tarap signifikansi 0,05.

Uji normalitas dilakukan untuk mengetahui apakah data yang diperoleh dari hasil penelitian berupa prestasi belajar siswa (pretes dan posttest) dari kelompok eksperimen dan kontrol terdistribusi normal atau tidak. Uji normalitas pada penelitian ini menggunakan Uji Kolmogorow-Smirnov dengan program SPSS versi 23 seperti dapat dilihat pada Tabel 1.

Tabel 1 Uji Normalitas

\begin{tabular}{|c|c|c|c|c|c|}
\hline \multirow[b]{2}{*}{ Kelas } & & \multicolumn{4}{|c|}{ Kolomogorov-Smirnov } \\
\hline & & Statistic & & $D f$ & Sig. \\
\hline \multirow{3}{*}{ Pretest } & Kontrol & .214 & & 10 & $.200^{*}$ \\
\hline & Eksperimen & & .200 & 10 & $.200^{*}$ \\
\hline & Kontrol & .201 & & 10 & $.200^{*}$ \\
\hline Posttest & Eksperimen & .167 & & 10 & $.200^{*}$ \\
\hline
\end{tabular}

Caruban: Jurnal Ilmiah Pendidikan Dasar 3(1), 93-106, Januari 2020

DOI: http://dx.doi.org/10.33603/.v3i1.3278, p-ISSN 2615-1391, e-ISSN 2620-3219

CProdi PGSD Universitas Swadaya Gunung Jati 
Berdasarkan hasil output uji normalitas menggunakan Uji Kolomogorov-Smirnov dengan SPSS versi 23, terlihat pada kolom signifikasi data nilai tes pretest dan posttest kelas kontrol maupun kelas eksperimen dikatakan berdistribusi normal karena nilai signifikasi kedua kelas baik pretest dan posttest tersebut lebih dari 0,05. Basuki (2015: 86) menyatakan bahwa "jika nilai signifikasi pada kolomogrovSmirnov < 0,05 data tidak menyebar normal dan jika nilai signifikasi pada kolomogrov-Smirnov > 0,05 maka data menyebar normal." Selanjutnya dilakukan uji homogenitas menggunakan One Way Anova, Adapun Hipotesisnya adalah sebagai berikut.

$H_{o}$ : Variansi Populasi sama (homogen)

$\mathrm{H}_{1}$ : Variansi Populasi tidak sama (tidak homogen)

Basuki (2015: 47) menyatakan bahwa "ketentuan jika signifikasi (sig. 2-tailed) > 0,05, maka data tersebut sama atau homogen dan Ho diterima, sebaliknya jika signifikasi (sig. 2-tailed) <0,05 data tidak homogen dah Ho ditolak."

Setelah dilakukan pengelolaan data dengan menggunakan program SPSS versi 23 tampilan output dapat dilihat pada Tabel 2 dan 3, bahwa nilai signifikasi data nilai Pretest 0,847 yang berarti $>0,05$ dan signifikasi data nilai Posttest 0,113 yang berarti $>0,05$, maka Ho diterima, sehingga data dapat dijelaskan bersifat homogenitas.

Tabel 2 Uji Homogenitas Nilai Pretest

\begin{tabular}{cccc}
\hline Levene Statistic & $d f 1$ & $d f 2$ & Sig. \\
\hline .038 & 1 & 18 & .847 \\
\hline
\end{tabular}

Tabel 3 Uji Homogenitas Nilai Posttest

\begin{tabular}{cccc}
\hline Levene Statistic & $d f 1$ & $d f 2$ & Sig. \\
\hline 2.768 & 1 & 18 & .113 \\
\hline
\end{tabular}

Setelah data kelas eksperimen dan kelas kontrol diuji dengan uji normalitas dan uji homogenitas, Menurut Basuki (2015: 83), "metode statistika yang mengharuskan terpenuhinya asumsi normalitas disebut statistika parametrik, sedangkan metode statistika yang digunakan untuk data tidak berdistribusi 
normal disebut statistika non parametrik." Berdasarkan hasil analisis posttest kelas eksperimen dan kelas kontrol diperoleh data yang berdistribusi normal mempunyai data yang homogen. Statistik parametrik merupakan analisis data yang menghendaki pengujian seperti normalitas, distribusi dan homogenitas data." Selanjutnya uji hipotesis dilakukan untuk melihat pengaruh model pembelajaran Market Place Activity (MPA) bebantuan poster terhadap prestasi belajar siswa kelas V SD IT At-Taufiq Al-Islamy pada tema 6 subtema 1 muatan IPA.

Uji hipotesis yang dilakukan dalam penelitian ini adalah independent sample ttest. Uji ini dilakukan untuk mengambil keputusan apakah hipotesis diterima atau ditolak. Wibowo (2010: 43) menyatakan bahwa "independent sample t-test merupakan teknik statistik parametrik yang digunakan untuk menguji perbedaan antar kelompok." Setiap uji hipotesis ternyata mempunyai asumsiasumsi tersendiri sebelum dilakukan uji hipotesis tersebut, baik parametrik atau nonparametrik. Seperti halnya menggunakan independent sample t-test ada asumsinya, menurut Wibowo (2010: 43), “Uji asumsi yang mengikuti penelitian ini terdiri dari uji normalitas dan homogenitas." Hasil output dengan menggunakan independent sample t-test pada program SPSS versi 23 dapat dilihat pada Tabel 4.

Tabel 4 Hasil Independent Semple T-Test

Levene's Test
for Equality
of Variances t-test for Equality of Means

95\% Confidence

Std. Error Interval of the

\begin{tabular}{|c|c|c|c|c|c|c|c|c|c|c|}
\hline \multirow[b]{3}{*}{$\begin{array}{l}\text { Prestasi } \\
\text { Belajar }\end{array}$} & & \multirow[b]{2}{*}{$F$} & \multirow[b]{2}{*}{ Sig. } & \multirow[b]{2}{*}{$T$} & \multirow[b]{2}{*}{$D f$} & \multirow{2}{*}{$\begin{array}{l}\text { Sig. (2- } \\
\text { tailed) }\end{array}$} & \multirow{2}{*}{$\begin{array}{l}\text { Mean } \\
\text { Difference }\end{array}$} & \multirow{2}{*}{$\begin{array}{l}D \\
\text { ifference }\end{array}$} & \multicolumn{2}{|c|}{ Difference } \\
\hline & & & & & & & & & Lower & Upper \\
\hline & $\begin{array}{l}\text { Equal } \\
\text { varianc }\end{array}$ & & & & & & & & & \\
\hline & $\begin{array}{l}\text { es } \\
\text { assume } \\
d\end{array}$ & 2.768 & .113 & 4.372 & 18 & .000 & 18.600 & 4.255 & 9.661 & 27.539 \\
\hline
\end{tabular}

Caruban: Jurnal Ilmiah Pendidikan Dasar 3(1), 93-106, Januari 2020

DOI: http://dx.doi.org/10.33603/.v3i1.3278, p-ISSN 2615-1391, e-ISSN 2620-3219

CProdi PGSD Universitas Swadaya Gunung Jati 
Levene's Test

for Equality

of Variances t-test for Equality of Means

95\% Confidence

Std. Error Interval of the

\begin{tabular}{|c|c|c|c|c|c|c|c|c|}
\hline \multirow[b]{2}{*}{$F$} & \multirow[b]{2}{*}{ Sig. } & \multirow[b]{2}{*}{$T$} & \multirow[b]{2}{*}{$D f$} & \multirow{2}{*}{$\begin{array}{l}\text { Sig. }(2 \\
\text { tailed) }\end{array}$} & \multirow{2}{*}{$\begin{array}{l}\text { Mean } \\
\text { Difference }\end{array}$} & \multirow{2}{*}{$\begin{array}{l}D \\
\text { ifference }\end{array}$} & \multicolumn{2}{|c|}{ Difference } \\
\hline & & & & & & & Lower & Upper \\
\hline
\end{tabular}

\section{Equal}

varianc

es not

$\begin{array}{llll}4.372 & 16.134 & .000 & 18.600\end{array}$

4.255

9.587

27.613

assume

$d$

Hasil analisis uji-t ( $t$-test) terhadap prestasi belajar siswa pada tema 6 subtema 1 muatan IPA. F test digunakan untuk menguji asumsi dasar t-test bahwa kedua kelompok sama, Setyawarno (2016: 16) menyatakan bahwa "ketentuannya jika nilai signifikansi > 0,05 maka homogen dan jika <0,05 maka tidak homogen."

Menurut Setyawarno (2016: 16), jika sig > 0,05, maka menggunakan baris bagian atas (equal variances assumed), namun apabila dalam perhitungan signifikansi < 0,05, maka memakai nilai baris yang bawah". Berdasarkan Tabel 4 di atas nilai signifikansi 0,113>0,05, maka menggunakan bagian atas (equal variances assumed). Dalam penelitian ini peneliti membuat rumusan hipotesis sebagai berikut.

$\mathrm{Ha}$ : Terdapat pengaruh penerapan model pembelajaran Market Place Activity (MPA) berbantuan poster terhadap prestasi belajar kelas $\mathrm{V}$ SD IT At-Taufiq Al-Islamy Pada Tema 6 Subtema 1 Muatan IPA.

Ho : Tidak terdapat pengaruh penerapan model pembelajaran Market Place Activity (MPA) berbantuan poster terhadap prestasi belajar kelas V SD IT At-Taufiq Al-Islamy Pada Tema 6 Subtema 1 Muatan IPA.

Diketahui bahwa t hitung sebesar 4,372 dengan probabililitas signifikansi (two tailed) 0,000, karena signifikansi (two tailed) < 0,05, maka Ho ditolak dan Ha diterima, artinya terdapat pengaruh model pembelajaran Market Place Aktivity 
(MPA) berbantuan poster terhadap prestasi belajar kelas V SD IT At-Taufiq AlIslamy Pada Tema 6 Subtema 1 Muatan IPA. Hal itu juga didukung oleh nilai rata-rata posttest kelas eksperimen sebesar 84,8, lebih besar daripada kelas kontrol yaitu sebesar 66,2. Dapat disimpulkan bahwa terdapat pengaruh positif dengan menerapkan model pembelajaran Market Place Aktivity (MPA) berbantuan poster terhadap prestasi belajar kelas V SD IT At-Taufiq Al-Islamy Pada Tema 6 Subtema 1 Muatan IPA.

Penelitian ini telah membuktikan bahwa model pembelajaran Market Place Activity (MPA) berbantuan poster lebih baik dibandingkan model konvesional (ceramah) terhadap prestasi belajar siswa kelas V SD IT At-Taufiq Al-Islamy pada tema 6 subtema 1 muatan IPA, dalam pembahasan ini akan dijelaskan hasil penelitian. Setelah dilakukan analisis, pada pretest di kelas kontrol dan di kelas eksperimen bahwa hasilnya tidak terlalu terdapat perbedaan karena terlihat dari masing-masing rata-rata kelas tidak terlalu jauh perbedaannya yaitu pada kelas kontrol 46,4 dan pada kelas eksperimen 46,2. Sedangkan perbedaan rata-rata pada hasil posttest kelas eksperimen mencapai 84,8 dan kelas kontrol 66,2 sehingga dapat disimpulkan bahwa terdapat perbedaan ratarata prestasi belajar siswa secara signifikan pada posttest kelas eksperimen dan kelas kontrol. Berdasarkan analisis yang telah diuraikan di atas, diperoleh hasil bahwa model pembelajaran Market Place Activity (MPA) berbantuan poster berpengaruh pada prestasi belajar siswa pada tema 6 subtema 1 muatan IPA materi suhu dan kalor.

Model Market Place Activity (MPA) Berbantuan Poster ini membuat anak berperan aktif di dalam pembelajaran, anak ada yang berperan sebagai penjual informasi yaitu yang menjelaskan informasi ke kelompok lain dengan bantuan poster yang dibuat bekerja sama dengan anggota kelompoknya, sehingga melatih anak supaya dapat menyampaikan informasi atau materi yang dipelajarinya ke temannya dan ada yang berperan sebagai pembeli dimana anak berkeliling ke kelompok lain untuk membeli informasi dan pembeli informasi ini diberi lembaran instrumen penilaian untuk menilai penjual dari kelompok lain, sehingga disini anak dilatih untuk dapat menyimak informasi

Caruban: Jurnal Ilmiah Pendidikan Dasar 3(1), 93-106, Januari 2020

DOI: http://dx.doi.org/10.33603/.v3i1.3278, p-ISSN 2615-1391, e-ISSN 2620-3219

CProdi PGSD Universitas Swadaya Gunung Jati 
dari temannya dan anak dilatih untuk dapat menilai temannya dalam menyampaikan informasi. Sehingga siswa dapat berperan aktif dalam proses pembelajaran. Sedangkan pada pembelajaran model konvesional (ceramah) guru yang sangat berperan, siswa banyak duduk mendengarkan penjelasan guru. Keaktifan dibatasi dalam proses pembelajaran tersebut, hal demikian menyebabkan siswa tidak mendapatkan kesempatan untuk mengembangkan pengetahuannya. Faktor lain yang mungkin menyebabkan adanya presentase hasil belajar siswa, bahwa kelompok eksperimen menggunakan model Market Place Activity (MPA) berbantuan poster menggunakan LKS yang menuntut siswa untuk lebih aktif dalam melaksanakan percobaaan dan diskusi, siswa akan memiliki motivasi belajar ketika dilibatkan untuk merumuskan masalah sendiri sehingga siswa akan lebih aktif dalam proses pembelajaran. Sedangkan pada kelompok kontrol hanya mencakup buku biasa yang seperti halnya guru lakukan saat melakukan pembelajaran dengan model konvesional (ceramah), guru yang lebih aktif sehingga tidak ada kesempatan untuk mengembangkan potensi yang dimiliki.

Keterbatasan dalam penelitian ini yaitu waktu dalam pelaksanaan pembelajarannya sangat berdekatan antara kelas eksperimen dan kelas kontrol, seperti di satu hari itu jam pertama pembelajaran tematik masuk di kelas eksperimen dan jam kedua pembelajaran tematik masuk di kelas kontrol, sehingga sedikitnya waktu untuk mempersiapkan proses pembelajaran. Hal ini dilakukan atas pertimbangan wali kelas karena setiap tema memiliki jadwal waktu yang telah ditentukan. Adapun kesan yang peneliti rasakan selama penelitian ini sangat berteri makasih, karena selama penelitian ini peneliti banyak mendapatkan ilmu dan pengalaman baru saat mengajar baik di kelas eksperimen maupun di kelas kontrol, dengan pengalaman tersebut peneliti bisa mengembangkanya nanti ketika sudah mengajar di Sekolah Dasar. Kelebihan selama penelitian yaitu siswa terlihat senang dan bersemangat dengan materi yang diajarkan dengan menggunakan model Market Place Activity (MPA) berbantuan poster.

Caruban: Jurnal Ilmiah Pendidikan Dasar 3(1), 93-106, Januari 2020

DOI: http://dx.doi.org/10.33603/.v3i1.3278, p-ISSN 2615-1391, e-ISSN 2620-3219

CProdi PGSD Universitas Swadaya Gunung Jati 
Hasil penelitian ini menujukkan bahwa terdapat perbedaan peningkatan prestasi belajar siswa dengan menerapkan model Market Place Activity (MPA) berbantuan poster pada tema 6 subtema 1 muatan IPA kelas V SD IT At-Taufiq Al-Islamy hal ini dilihat dari rata-rata nilai kelas eksperimen yang lebih tinggi daripada kelas kontrol. Hal ini membuktikan bahwa dengan menggunakan model Market Place Activity (MPA) berbantuan poster, siswa lebih memahami materi dan siswa dapat berperan aktif dalam proses pembelajaran. Berdasarkan hasil penelitian di atas memiliki beberapa implikasi terhadap pelayanan, pendidikan dan penelitian.

Implikasi terhadap pelayanan pada penelitian ini bagi siswa yang melaksanakan pembelajaran menggunakan model Market Place Activity (MPA) berbantuan poster ternyata mampu melatih siswa untuk belajar mandiri, berdiskusi dengan kelompok dan dapat meningkatkan prestasi belajar siswa pada tema 6 subtema 1 muatan IPA materi suhu dan kalor. Implikasi terhadap pendidikan di penelitian ini menemukan pembelajaran bahwa guru memberikan kontribusi yang besar terhadap terbentuknya proses pembelajaran yang kondusif. Untuk menciptakan suasana pembelajaran yang kondusif, banyak cara yang digunakan misalnya dengan menerapkan model pembelajaran, media pembelajaran yang menarik, teknik pembelajaran dan cara-cara yang dapat menumbuhkan semangat siswa saat belajar.

Model pembelajaran tentu banyak macamnya, tetapi dalam setiap model pembelajaran akan mempunyai kelebihan dan kelemahannya masing-masing. Temuan penelitian ini adalah bahwa model Market Place Activity (MPA) berbantuan poster berpengaruh baik terhadap prestasi belajar siswa pada tema 6 subtema 1 muatan IPA materi suhu dan kalor, serta bagi guru sebagai bahan kajian model Market Place Activity (MPA) berbantuan poster untuk diterapkan dalam materi yang sama atau materi berbeda, bahkan pada mata pelajaran yang berbeda, dalam upaya meningkatkan prestasi belajar siswa. Model Market Place Activity (MPA) berbantuan poster dapat dijadikan sebagai bahan acuan untuk mengadakan penelitian selanjutnya tetapi mungkin dengan permasalahan yang berbeda.

Caruban: Jurnal Ilmiah Pendidikan Dasar 3(1), 93-106, Januari 2020

DOI: http://dx.doi.org/10.33603/.v3i1.3278, p-ISSN 2615-1391, e-ISSN 2620-3219

CProdi PGSD Universitas Swadaya Gunung Jati 


\section{Simpulan dan Rekomendasi}

Berdasarkan analisis data pembahasan diperoleh kesimpulan bahwa model Market Place Activity (MPA) berbantuan poster berpengaruh baik terhadap prestasi belajar pada tema 6 subtema 1 muatan IPA materi suhu dan kalor kelas V SD IT At-Taufiq Al-Islamy. Hal ini dibuktikan dari uji hipotesis dengan signifikasi (two tailed) 0,000 <0,05, itu artinya Ho ditolak, setelah itu dilihat dari rata-rata posttest kelas eksperiemen lebih tinggi dari posttest kelas kontrol, Nilai posttest pada kelas kontrol sebesar 66,2 dan kelas eksperimen sebesar 84,8 .

Adapun rekomendasi yang diberikan dalam penelitian ini adalah kepada pembaca dan peneliti lain yang akan melakukan penelitian tentang pengaruh model Market Place Activity (MPA) berbantuan poster terhadap prestasi belajar siswa, hendaknya dalam pelaksanaan pembelajaran model ini siswa harus dikondisikan terlebih dahulu agar lebih siap untuk belajar, supaya proses pembelajaran sesuai dengan yang sudah direncanakan sebelumnya. Untuk penelitian yang selanjutnya disarankan diterapkan pada mata pelajaran yang berbeda, supaya dapat diketahui apakah model Market Place Activity (MPA) berbantuan poster ini dapat berpengaruh terhadap prestasi siswa.

\section{Daftar Pustaka}

Basuki, Agus T. 2015. Analisis Statistik dengan SPSS. Banyu meneng: Danissa Media.

Depdiknas. 2003. Undang-undang RI No 20, Tahun 2003, Tentang Tujuan Pendidikan Nasional.

Djamarah, Bahri, S. 2017. Prestasi Belajar dan Kompetensi Guru. Surabaya: Usaha Nasional.

Indrawan, Rully, \& Yaniawati, Poppy. 2017. Metode Penelitian Kuantitatif Kualitatif dan Campuran. Bandung: PT Revika Aditama.

Niska, Bakhiti. 2013. Penggunaan Media Poster Untuk Peningkatan Hasil Belajar Siswa Pada Pelajaran Pendidikan Kewarganegaraan Di Sekolah Dasar. Jurnal PGSD. Vol. 01. No 02. 0-216. Diunduh pada tanggal 21 November 2019 jam 19.35. WIB.

Caruban: Jurnal Ilmiah Pendidikan Dasar 3(1), 93-106, Januari 2020

DOI: http://dx.doi.org/10.33603/.v3i1.3278, p-ISSN 2615-1391, e-ISSN 2620-3219

CProdi PGSD Universitas Swadaya Gunung Jati 
https://scholar.google.co.id/scholar?hl=id\&as sdt=0\%2C5\&q=bakhiti+nisk $\underline{a}+$ penggunaan+media+poster+untuk+peningkatan+hasil+belajar\&btnG $=\#$ $\mathrm{d}=\mathrm{gs}$ QABS\&U=\%23p\%3DMDKwfG6YxroI.

Setyawarno, Didik 2016. Panduan Statistik Terapan Untuk Penelitian Pendididkan. Yogyakarta: Pendidikan IPA FMIPA UNY

Sugiyono. 2016. Metode Penelitian Pendidikan. Bandung: CV Alfabeta.

Sumantri, Syarif, M. 2015. Strategi Pembelajaran. Depok: PT Rajagrafindo Persada.

Wibowo, Satrio B. 2010. Modul Pelatihan SPSS. Lampung. Universitas Muhammadiyah Metro. 